Nowoczesne Systemy Zarządzania

Zeszyt 15 (2020), nr 2 (kwiecień-czerwiec)

ISSN 1896-9380, s. 13-30

DOI: $10.37055 / \mathrm{nsz} / 132932$

Modern Management Systems

Volume 15 (2020), No. 2 (April-June)

ISSN 1896-9380, pp. 13-30

DOI: $10.37055 / \mathrm{nsz} / 132932$
Instytut Organizacji i Zarządzania Wydział Bezpieczeństwa, Logistyki i Zarządzania

Wojskowa Akademia Techniczna

w Warszawie

Institute of Organization and Management Faculty of Security, Logistics and Management Military University of Technology

\title{
Development Perspectives, Threats and Implementation Limitations of the Industry 4.0 Concept
}

\section{Perspektywy rozwoju, zagrożenia i ograniczenia wdrażania koncepcji Przemysłu 4.0}

\author{
Piotr Zaskórski \\ Military University of Technology, Faculty of Security, Logistics and Management \\ piotr.zaskorski@wat.edu.pl, ORCID: 0000-0002-2598-1859 \\ Robert Wiczyński \\ DBSchenker - Technology Solution Center (TSC Warsaw), \\ Release Manager, Global Automation Competence Center \\ wiczynski.robert@gmail.com
}

\begin{abstract}
Abstract. The paper attempts to systematically approach of implementation of technologies determined by the Industry 4.0 concept by indicating the possibility of using selected solutions in the context of identifying their advantages, but also threats and limitations. Based on this analysis, it has been proposed to use modern information technologies, including the integration of information databases. Moreover, the role of multi-faceted data mining was highlighted. This applies in particular to supporting decision-making processes through ongoing monitoring of the implementation of production and service processes in relation to the customer's needs. All threats and disruptions in information systems may cause the risk of disruptions in the value chain generated by the implementation of the Industry 4.0 concept.

Keywords: Industry 4.0, strategy, systems, IT tools, threats
\end{abstract}

Abstrakt. W artykule przedstawiono systemowe podejście do wdrażania określonych technologii determinowanych specyfiką koncepcji Przemysłu 4.0, poprzez wskazywanie możliwości wykorzystania wybranych rozwiązań w kontekście identyfikacji ich zalet, ale także zagrożeń i ograniczeń. Na podstawie tego typu analizy zaproponowano wykorzystanie nowoczesnych technologii informacyjnych, w tym integrację baz danych. Ponadto podkreślono rolę wieloaspektowej eksploracji danych. Dotyczy to w szczególności wspierania procesów decyzyjnych poprzez bieżące monitorowanie wdrażania procesów produkcyjnych i usługowych w odniesieniu do potrzeb klienta. Wszystkie zagrożenia i zakłócenia w systemach informacyjnych mogą powodować ryzyko zakłóceń w łańcuchu wartości - wynikających z wdrożenia koncepcji Przemysłu 4.0. Słowa kluczowe: Przemysł 4.0, strategia, systemy, narzędzia IT, zagrożenia 


\section{Introduction}

The concept of Industry 4.0 - often called the fourth industrial revolution - is becoming a fact and creates a new reality with a certain, contractual dilemma as to whether it is virtual reality or real virtuality? It is not just a condition (snapshot), but a whole complex process that consists of many years of evolutionary activities. Changes in the operationalization and management models of contemporary organizations have been and are successively forced by the technical and technological base in many areas of peoples' activities, including, first of all, the level of computerization, production process automation services, as well as management and control processes. The criteria formulated for the concept of Industry 4.0 (Min Xu et al., 2018; Gilchrist, 2016, pp. 1-86) illustrate quite clearly that without an appropriate level of saturation with information technologies the effective implementation of its assumptions is not possible. Therefore, one should be aware of numerous barriers and limitations, with a significant range of advantages and expected benefits.

The base of efficient tools and information technologies, including systems supporting and integrating management and control processes with service and manufacturing industry becomes an inherent feature of every modern business entity, which is associated with the need to enrich and modernize the technical and technological IT base, both own and, above all, available in the cyberspace. There is a strong convergence of IT and management. It is observable especially in the concepts of creating and operationalization of process organizations, which in real time (on-line) are able to react to turbulent changes in the environment. These canons are becoming the main challenge of modern business. "Flattening" management structures, networking organizations and working on common ones information resources may result in strengthening one's own potential with simultaneous emphasis on the cooperation of various entities, and not on competition. This is conducive to informational business continuity (Zaskórski, Woźniak et al., 2020) as well as shared situational awareness and the implementation of the set group goals, not only corporate ones.

The concept of the fourth industrial revolution is based directly on the need to integrate various types of systems towards lean ("flat") organizations (horizontally oriented towards cooperation) in a global environment. The network model (combination of equivalent entities) and exposure of the partnership based on reliable sharing of information resources about the state and forecasts of activities enables the individualization of the needs of a modern client, taking into account quality as a dominant criterion in the assessment of the entire established organization. The response time to individual customer needs combined with a high level of materialization of innovative solutions (Dugan, Gabriel, 2013) is one of the criteria for acceptability of the assumptions and goals of the Industry 4.0 concept. The quick adaptation of an organization to changing expectations of clients becomes an important component of the quality of its functioning. 


\section{Evolution of the management model determined by digital technologies}

The dynamics of changes in the functioning models of modern organizations is becoming more and more intense. This phenomenon is already visible in the development chain, starting from the first industrial revolution (mechanized production in the 18th century), through the second revolution at the beginning of the 20th century (mass production using electricity) and the third technological revolution (the 1970s, high-tech industry). Technology, programmable computer logic circuits) until the beginning of the 21st century, when the fourth industrial revolution imposes the need to integrate digital systems with physical systems, based on dynamic data processing. This is due both to the achievement of an appropriate level of technological development (saturation), as well as the possibility of integrating various types of solutions related to the increasing use of the Internet platform and the Internet of Things, as well as systems processing a large amount of data (Big-Data).

The fourth industrial revolution is a direct continuation of the third industrial revolution that brought automation and robotization. Many autonomous solutions related to the automation and digitization of production were created, e.g. industrial robots. Contemporary organizations aim to discount and integrate these advanced technologies through the strong use of the information layer and ICT, including artificial intelligence and machine learning (AI/Artificial Intelligence and ML/ Machine Learning). Such solutions are used in many areas, including, for example, the IT services sector (AIOps/Artificial Intelligence for IT Operations), where the response time to an incident is crucial in the context of reducing losses and costs. Therefore, the aim is to integrate fast data processing technologies with physical service and production systems. Hence, there are problems with the integration of autonomous robots, the use of simulation models and tools and the Internet of Things (including industrial IIoT/Industry Internet of Thing) and systems for processing large volumes of multi-form data together with advanced business analytics models. Information integration processes may support the processes of organizational and functional integration (vertical integration of many detailed solutions). The processes of collecting and archiving as well as sharing data require appropriate cybersecurity tools (e.g. blockchain tools). Many information services and supporting the management (cooperation) process of various entities are and will be located in cyberspace. Cloud computing is becoming an increasingly common medium not only of communication, but above all of the availability and implementation of technologically advanced information processes and services.

Access to rich information resources and their quick selection and analysis combined with the generation of knowledge make it possible to effectively assess - in various time horizons and at various stages of development - the business situation 
in the local and global dimension. It is possible to monitor the state of resources and the possibilities of operating in the international space. These assessments can be carried out in many dimensions and focus on forecasted and real possibilities of geographically dispersed potential. Simulation tools and models enable comprehensive forecasting of market needs and the behavior of customers and potential partners (participants). Access to rich constellations of data and information may also help counteract business risk and possible threats. Moreover, enhancing the operating capacity of contemporary distributed (network) organizations in contemporary conditions is determined by the special role of efficiency and reliability in the implementation of information and decision-making processes. The efficiency of these processes depends on quick access to selected resources and information services. Modern IT technologies quite effectively eliminate numerous financial and technological limitations.

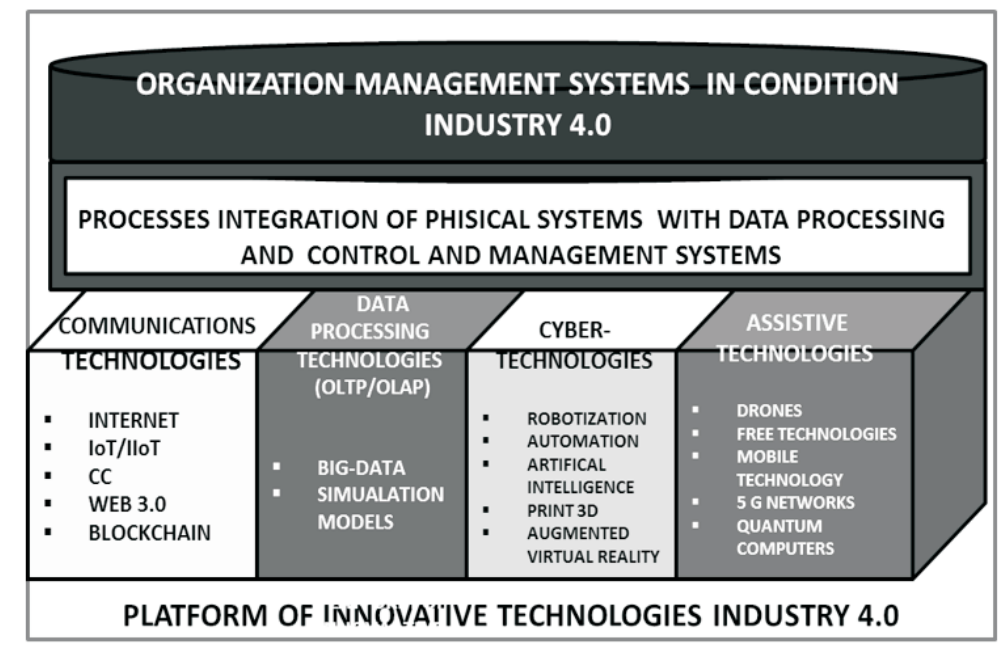

Fig. 1. Selected technologies of the fourth industrial revolution

Source: Own study based on: Gilchrist, 2016, pp. 153-216; Ogórek, Zaskórski, 2018

The Industry 4.0 concept assumes the creation of a fully integrated system of suppliers, producers and customers by integrating processes and resources as well as measures of operation without time and place limitations. Such an integrated system is both effective when monitoring with the use of integrated systems and mechanisms for monitoring and recording on-line (Fig. 1). The contemporary environment of collecting systems (databases) and processing of operational data (OLTP) and the integrated environment for collecting and analytical processing (historical data warehouses, OLAP systems) is already a strong support for 
decision-making processes (Zaskórski, 2012, pp. 245-280). Various limitations of data form and classic models of knowledge obtaining/creating (data-mining) as well as organizational and financial limitations lead to the use of standards and services located on the CC platform and Big-Data technology, and simulation techniques. IoT platform, in particular the so-called Industrial IoTwill increase the power and timeliness of information resources. The combination of these various potentials, together with the technologies described, becomes an important component of the Industry 4.0 concept.

According to the Industry 4.0 concept, IT solutions should be integrated with all subsystems and processes as well as resources of various systems, as well as with the networks of suppliers and customers. This concept is therefore to make the use of autonomous digital systems (physical and even biological) become a reality (the disappearance of the barrier between human and machine). Thus, an environment for creating innovative business solutions will be created. The innovative technologies of the 4th industrial revolution include many - apart from IoT, Big-Data, CC - technologies such as:

- Wireless technologies and 5G high-capacity networks;

- Artificial intelligence, machine learning and computer simulation models;

- Augmented and Virtual Reality;

- Robotics, drones and implantable technologies;

- $3 \mathrm{D}$ printing technologies;

- Mobile technologies, web 3.0 and Blockchain technology (cybersecurity);

- Advanced supervisory and control systems SCADA (Supervisory Control and Data Acquisition);

- Quantum computers etc.

The above-mentioned platforms and technologies constitute the basis for the integration processes (Fig. 1) of various systems. A special role is played by the web 3.0 environment and IT systems supervising the course of the technological and production process (SCADA), taking into account advanced functions of collecting current data (measurements), their visualization and archiving, and above all, control and ongoing monitoring of a given process. The Web 3.0 environment should be treated as the next phase of Web 1.0 and Web 2.0 development. This environment is based on the integration of data sources and information in a special way, enabling extended data mining and online reasoning based on monitored reality (IoT). Complementary mechanisms can be Big-Data technologies and knowledge discovery models based also on artificial intelligence (the potential of IoT integration with Big-Data using AI solutions and machine learning). Therefore, it is an approach focused not only on the user's information needs, but also on the creation and satisfaction of their expectations (anomaly detection and anticipation of future needs are one of the main elements of business development). 


\section{Communication platform}

The environment of Internet, the Internet of Things (IoT) and the Industrial Internet (IIoT) is an universal platform for acquiring and exchanging data and information about the state of a specific process or object. Hence the coupling and use of devices and sensors connected with Internet in order to increase the usability, reliability, efficiency and effectiveness of entities (functioning of systems). On-going measurements by network-coupled sensors can generate various types of data important for the quality of the overall business process. Moreover, these measurements can be multi-faceted and related, for example, to the customer's environmental factors or the state of production and the technology park, etc. Created - comprehensive and complementary - data resources provide a more complete picture useful in the automation of processes, increasing their efficiency and security (Basole, Park, 2019, pp. 369 et seq.), as well as in the optimization of resource consumption in general. The information obtained can therefore be used to improve the supply chain and design new products.

Among business decisions, it is important to create an effective, efficient and secure communication platform. The Internet environment and its developed models dedicated to various recipients are therefore becoming a common communication platform that allows access to various resources and services. One of the modern solutions strengthening this aspect of using Internet is the cloud computing environment (Fig. 2), oriented to the possibility of reducing expenses on the necessary hardware and software as well as on their configuration and maintenance of appropriate infrastructure (Basole, Park, 2019, pp. 370-379; Vijayakumar, Arun, 2017, pp. 129-136). Important are also other attributes of this service class in the CC environment, such as the ability to:

- Dynamic and flexible scaling of the recipient's information needs, which means that it is necessary to provide as many appropriate IT resources as the user requires in a given period (e.g. more computing power at the required place and time).

- Increasing productivity and improving speed according to autonomous requirements and providing services on demand.

- Providing safe and efficient services using a network of secure data centers where technology is constantly updated, making the latest generation of hardware and software available.

- Ensuring the security and reliability of information processing processes, including the use of data recovery procedures in the event of their loss, which is particularly important for maintaining information security ( $\mathrm{Da}$ Veiga and Others, 2020, pp. 2-20) and information and business continuity of operations (Zaskórski, 2011, pp. 145-170) of a specific entity (business organization). 


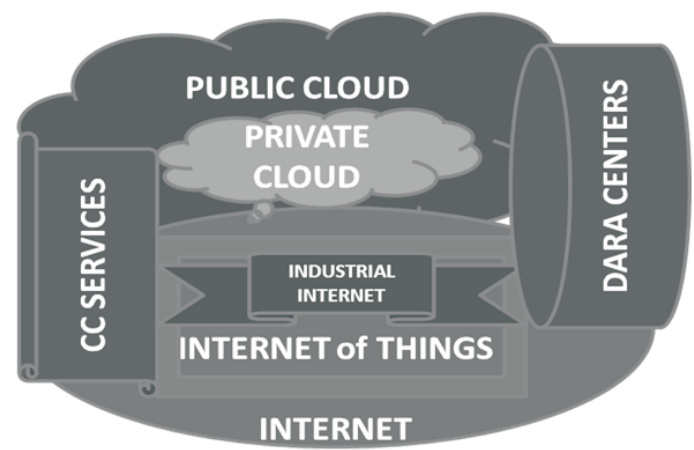

Fig. 2. Integration of IT services with the use of CC services Source: Own study

The CC environment is a platform of many services that offers unlimited development opportunities and creates conditions for the emergence and development of the modern market. Many new innovative companies that have been recently established are using CC services which enable them to maximize their business operations. In addition, CC services are used today by global giants (Uber, Netflix, Airbnb, etc.), which are based on innovative business models that confirm the effectiveness of the adopted patterns, useful for other industries.

The CC platform can be perceived both in the perspective of public services (Public cloud) and services dedicated to selected entities (Private cloud) and services in the hybrid model (Hybrid cloud). Private clouds are part of an organization that is an autonomous service provider. Public clouds are a set of services served by external, generally available providers (e.g. Google, Amazon, etc.). Hybrid clouds offer combined private and public cloud services. The spectrum of cloud computing services is getting wider, ranging from IaaS (Infrastructure as a Service), PaaS (Platform as a Service) to SaaS (Software as a Service). IaaS is a service of providing IT infrastructure (hardware, software, e.g. in the form of virtual machines), PaaS is a platform that provides a service in the form of a virtual work environment, while SaaS provides the client with applications via Internet. An important supplement to this set of services is CaaS (Communications as a Service), which is a service provided as a communication environment. Transferring the entire software and system to a server with remote processing and communication in Internet is an advanced DaaS (Desktop as a Service) service for an individual client (Mateos, Rosenberg 2010, pp. 169-187). The CC platform meets selected assumptions of the Industry 4.0 concept in terms of combining the information needs of a specific entity with the possibility of using universal techniques and technologies of data processing according to your own service preferences. It also means that the concept of the fourth industrial revolution also limits the informational exclusion of smaller entities, which is especially important for various types of start-up companies. In 
addition, $\mathrm{CC}$ is a set of specific tools that make it possible to maintain the efficiency expected by customers in the provision of services and goods, while respecting the criterion of timeliness and the required level of security. Therefore, the customer is individualized by monitoring his needs with the use of advanced services for exploring large data resources (Big-Data) and a wide range of high-intensity information feeds using IoT (Miller, 2016) and IIoT (Gilchrist, 2016, pp. 153-160).

\section{Advanced services environment}

The concept of the fourth industrial revolution is associated with the transformation and development of fully automated production and service systems. The essence of this concept is the comprehensive use of automation and robotization, and the assumed final effect is to be the creation of intelligent things and factories. It should be noted, that the concept of Industry 4.0 is associated not only with modern technologies, but also forces a new organization of work. In the development of production, the new technologies introduced resulted in leaps ("revolutions"), which significantly changed the visions and directions of development of the world economy. This was the case in the first two industrial revolutions. The third revolution was a consequence of the introduction of information systems and technologies, which contributed to the digitalization of production, which made it possible to achieve an increasing degree of industrial automation. The fourth revolution "liberates" from clean production technology for the integration of various systems in the full cycle "from customer to customer". Hence, the processes of monitoring complex production processes combined with knowledge about the needs and preferences of the client become the basis of "built intelligence" or a system of intelligent behavior of decision makers. The creation of large databases and the development of networks (connecting not only people but also things) as a source of comprehensive data is a consequence of the need to integrate people and smart devices with Internet. This brings it closer and closer to the concept of intelligent factories, in which cyber-physical systems monitor physical processes, control decentralized operations and support decision-making (or even generate control of specific processes) in "almost" real time. The development and implementation possibilities of the Industry 4.0 concept in newer and newer areas must be aimed at integration with such environments as CC and IoT/IoE platform, Big Data systems, simulation models and systems, etc.

The Internet of Things, combining people and things (devices, machines, products, objects and their technical and organizational components, technological lines, etc.) into one network, becomes an important source of data for various advanced information technologies. According to the concept of the fourth industrial revolution, the purpose of this connection is to support manufacturing and service 
processes adapted to modern quality criteria of modern products and services. The development of IoT is associated with the emergence of new things that can exchange information (communicate) with each other and inform about their state and the value of selected attributes. This communication can map the connections between people and objects, and between objects (machines, ${ }^{1}$ products). By using a database of various sensors, both products, machines, tools, as well as various objects (e.g. means of transport), thanks to such connections, they can generate relevant information about themselves (e.g. about their location) on-line and exchange data with each other to provide the customer with the expected, high-quality product or service. The implementation and use of IoT platforms (IoE/IIoT) in the modern industrial sector is a necessary condition for its development. The implementation of IoT tools in the branches of the global economy is becoming a driving force for the emergence of intelligent production lines.

Along with the concept of Industry 4.0 (Design principles, 2020), the following concepts are introduced: Cyber Physical Systems, Internet of Things, Internet of Services, Smart Factory, Smart Product, Intelligent Product, Machine-to-Machine (M2M), Big Data, Cloud Computing (Chowdhury, 2018). Thus, the implementation and implementation of the concept in question must be based on the IoT platform with its innovative solutions. These solutions develop new production systems as well as services and tools needed for the industry. The implementation of new proven solutions offers a chance for better quality while reducing the costs associated with the business and manufacturing process. This is especially important for small and medium-sized enterprises, which quite often cannot afford their own individual innovative research and solutions. The rapid development of the Internet of Things and similar platforms coupled with it makes them cheaper, proven and easily available solutions with the development of the IT environment.

The area of application of technological solutions based on the IoT platform is already significant and continues to grow along with the development of newer and newer proposals for technological improvements, both in terms of new materials and solutions in the IT world. The entire system of modern socio-economic life, including modern industry, must seek and constantly implement new technologies in order to be able to keep up with the requirements and expectations of individual recipients (citizens). Today's customers force the production to adapt to their individual requirements. In the case of modern enterprises, these solutions support the transition to the process organization model. For modern industry, this means a shift to process structures that are able to dynamically and flexibly adapt to market requirements. The next challenge is then adapting and focusing on areas of human activity, in which there may be a significant integration of solutions based on the IoT platform with other control and management systems.

1 Communication between machines is called the M2M communication. 
Modern technologies that are to make life simpler and safer (Smart Life) are directly related to the implementation of IoT platforms in healthcare, banking, public services, etc. Smart Home, Smart Buildings and Infrastructure improve security and comfort of living not only in apartments, but also in public and industrial facilities. The modern model of smart city (Smart City) is the integration of many aspects of life and functioning of such a complex object (operation system), including intelligent management of urban infrastructure. Smart Manufacturing concerns a complex of issues related directly to the production process and its logistics, with the assumption of optimization of these processes. The production process includes monitoring and quality control processes. Following the collection of situational information, machine learning models and intelligent, automated decision-making can be used. In addition, the model of network operation of people and devices (networking) gives the possibility of network control and management (control) of production devices according to an optimized process structure. Logistics processes are often related to intelligent real-time route management (Smart Mobility) and transport autonomy (self-steering car). It is also an image of an IoT implementation. Intelligent energy and transmission systems (Smart Energy, Smart Grid) are of great importance for the implementation of the Industry 4.0 concept. The functionality of these solutions is derived from the use of information generated by IoT/IIoT devices.

A modern enterprise created and functioning according to the requirements of Industry 4.0 must be characterized by a flexible response to the changing conditions of the surrounding environment and appropriate adaptation abilities to these dynamic changes. An additional challenge is the ability to function in a dispersed environment of its subsystems and production resources, both material and non-material Fig. 3). This requires the ability to integrate various systems and components with the assumption of coherent operation in the modern business market. Modern enterprises based on the Industry 4.0 concept must be able - In addition to introducing technologically advanced devices - to make "intelligent" decisions based on the collected data on the implemented processes. Enterprises use various IT technologies and a variety of software, which may result in various data mining techniques. This applies to both different models of data acquisition and selection, as well as combining business data with technological or social data. This may constitute a certain technological barrier for smaller business entities. Selecting the information needed for a given company and the time in which we can have access to it may determine the competitiveness and survival of the company in the modern market. An additional challenge is the processing of this data, often with the use of systems residing in the CC environment. This requires ensuring adequate security and confidentiality, not only from data from heterogeneous sources (e.g. from a large number of different mobile devices, including IoT, in various forms), but also from processed data and analytical information. The solutions to these expectations are Big Data systems with their various solutions supported by artificial intelligence models using knowledge discovery processes (Zaskórski, Zaskórski, 2017). 
Big Data systems have the ability to collect, store and effectively explore various types of large-volume data. They require extensive technical and technological infrastructure. Processing such large-volume resources in a limited time is based on fast, high-computing computers and parallel data processing. The operation and use of this class of systems significantly increases the quality, accuracy and objectivity in assessing the functioning of the entire organization and the effectiveness of the processes implemented. This has a direct impact on the effectiveness of decisions made in a shorter period of time and with reduced operating costs. The concept of the fourth industrial revolution assumes the widespread use of Big Data technology also for the comprehensive assessment of the situation in production systems. This assessment becomes a driving mechanism in the control and management support systems of the enterprise. In addition, information about current customer relationships affects the accuracy of business decisions. This information results from the current data on their needs and preferences, which will become a standard that will support the decision-making process in real time.

Internet and the exploration of its information resources (Web Mining), combined with a quick selection and analysis of available data, becomes a determinant of the development of the concept. Integrating these resources and enriching them on an ongoing basis at a dynamic pace also through the growing number of mobile devices increases the content of Big Data systems. The success of this class of systems results not only from the possibility of collecting and analyzing data or the possibility of quick access to more detailed information, but above all from the possibility of creating and using interactive applications with the use of an appropriate communication platform. In the context of Industry 4.0, these are applications that enable communication between systems, objects and devices. This type of communication is an important component of integrated actions, including effective support for decision-making processes through interactive references and analyzes of current information resources of oneself and of the global environment (Fig. 3). The applications available today are able not only to forecast the development of the situation and related problems, but also to predict the effects of various actions and the possibility of counteracting these effects thanks to the use of simulation models and systems as well as neural networks, artificial intelligence and M2M technology. An important support for the effective use of these possibilities are applications that can select and deliver the required ranges of data to the indicated place and create appropriate decisions or initiate targeted actions.

In the concept of the fourth industrial revolution, it is recommended to strive for the universality of solutions, assuming the use of open technologies with the possibility of their expansion. Such solutions with a high level of scalability may become a catalyst for the development of companies with less potential (SMEs), which can use the available platforms and strengthen their market position and even become a competitor (e.g. startups) of large corporations. According to research 
by Infogroup (ERP24, 2019), today $62 \%$ of marketers in the world declare the use of marketing with the use of Big Data, and another $26 \%$ plan to use such solutions in the coming years. The modern business world recognizes the fact that the more data it collects about its customers and is able to effectively explore them, it obtains the necessary information and knowledge (using data-mining models and mechanisms), and thus also a greater chance of gaining customers and satisfying them their individual needs.

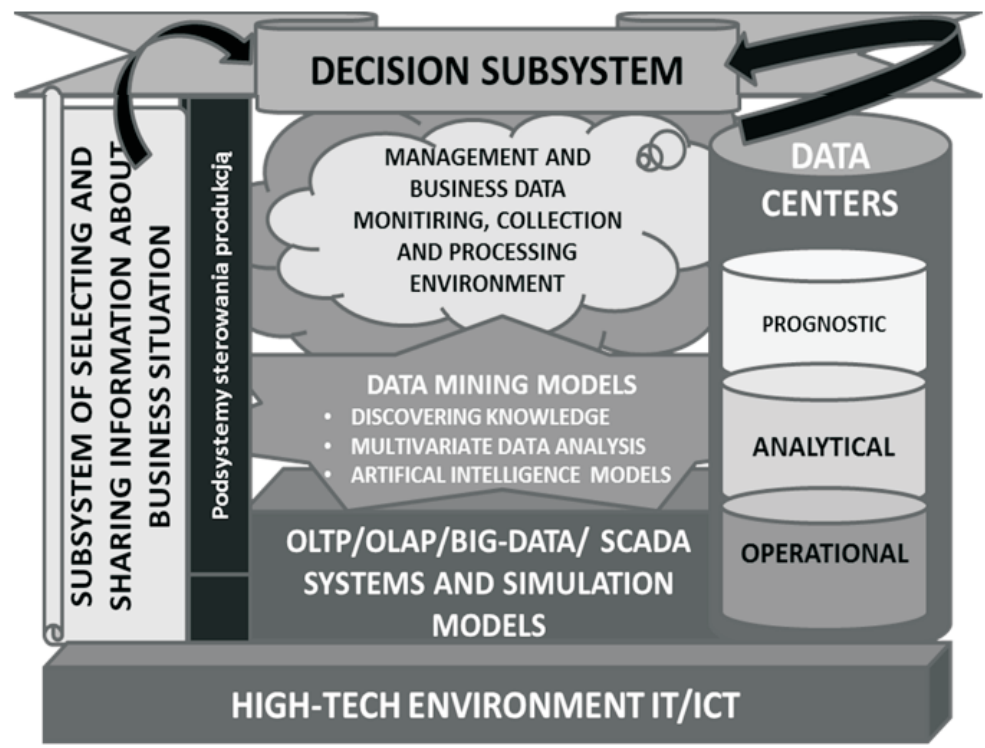

Fig. 3. Selected components of the environment of advanced cyber services Source: Own study

\section{Opportunities, risks and limitations of the implementation of the Industry 4.0 technology}

The key determinant of the risk of limited effectiveness and efficiency of technology implementation resulting from the assumptions of the fourth industrial revolution is the implementation of specific types of threats of organizational and technological nature and the partiality of certain information services. One should also pay attention to the limited mobility of IT solutions. Quantification and taxonomy of this class of business threats, including the so-called the threat of information exclusion may be made aware of the implementation barriers and limitations of the concept in question. The existing management paradigms pose 
quite significant threats to the implementation of the principles, rules and technologies that determine the Industry 4.0 concept. Hence, in order to reduce the risk of implementing technologies related to this concept, the current management paradigms should be counteracted, such as:

- Recognition of state borders as a method of restricting competition.

- physical and financial capital as the basic production factor.

- Access to information and technology limits the company's development.

- Centralization and bureaucratization of management, and managers are the sole holders of capital.

- The main goal of management is to generate profit.

- Companies produce goods on a mass scale and can influence and force customer loyalty.

- Workers are a vital but not the most important factor of production etc.

Awareness of these threats requires counteracting the above-mentioned factors and modifying the management models of a modern business organization in the direction of reducing the size of companies and partial decentralization of large corporations, transferring some power to employees, and above all, in the direction of increasing use of information technologies (ICT) in management processes, processes using the potential of the environment (X-engineering) and the use of extensive marketing campaigns. Successive introduction of this type of changes indicates a fundamental change in the management model to the so-called the "client-centric" model, in which the role of companies is to obtain information about the client's needs and keep up with the implementation of their individual expectations (Denning, 2020, p. 74). Hence the importance of integrating business systems with production systems.

The constant process of monitoring threats and risk evaluation (Senhar, Dvir, 2007, pp. 63-138) for various areas and phases of implementation of the fourth industrial revolution technology as well as the possibilities and needs of taking selected action strategies in the perspective of time-cost as well as organizational and economic criteria - requires access to be informed about the scope and effects of such implementations. This applies to both a new approach to market competition and cooperation of companies without formal borders (e.g. state) and the effects of such cooperation, as well as the creation of:

- Smart factories (Gilchrist, 2016, pp. 217-230) logistics systems and distributed production.

- Network organizational and inter-organizational constellations and creating new models of value chains.

- Innovative products and solutions as well as intelligent product connections on the IoT/IIoT platform.

- Big-Data platforms and the use of cloud computing solutions.

- New business models, forms of communication, robotization and other innovative solutions. 
The criterion of effective group work and shaping the common situational awareness of the participants of the contemporary, multi-entity management model becomes a natural support for sharing responsibility through the use of uniform and reliable information. The process of implementing new technologies should therefore be evaluated in terms of many threats. One of the ways of preventing threats to effective management is having access to up-to-date and verified data resources and the ability to obtain and verify them. The simulation systems available today in cyberspace can be a useful tool for effective forecasting and verification of the situation assessment and obtaining useful data.

Systems and simulation models in the Industry 4.0 concept can play a verification role for planned or even current activities. Simulation methods can support various processes, including decision-making in both production and management (Gajda, 2017, p. 11). Effective forecasting can prevent losses related to wrong investment or production decisions in today's complex organizations. Management models emphasize the effective use of resources to achieve the set goals. In the era of the fourth industrial revolution and the globalization of business processes, which is still going on today, information resources have gained their deserved importance, not only in strategic management. Increasingly, attention is paid to the role of interdisciplinarity in strategic management models in connection with the achievements of other fields, including cybernetics (IT, cyberspace, cybersecurity, etc.).

Effective management processes require access not only to operational data (data from the present), but also to data about the past and information resources about the future (planned activities, information and forecast data). Thus, in order to effectively obtain the expected data (including, for example, a proper forecast), it is necessary to support with tools enabling the determination and visualization of the forecasted reality (including causes and their effects). The collection of such tools includes models, systems and simulation methods that have dynamically developed along with new computer technologies. The use of these methods shows the use of various data, also residing in cyberspace. A more important dimension, however, is the fact that they can be a data generator that complements the image of various work and management processes in management support systems using the CC platform, as well as data warehouse systems (Zaskórski, 2012, pp. 245-280) or Big-Data class systems (Mayer-Schonenberger, Cukier, 2014).

Simulation systems with geospatial information tools such as GIS (with visualization of the situation) are tools that enable forecasting and observation of the operation of a selected system and its behavior through the use of advanced platforms and IT environments (Fig. 4). This allows organization to verify and present a specific situation. The simulation model allows - without incurring much higher expenditure than in real systems - to analyze complex problem situations with a large amount of data in a condensed time. And so, experiments and trials on real objects (often lasting several years and were expensive) can be replaced with a simulation 
that lasts shorter (e.g. several days or hours or minutes) depending on the available computing power (today on the CC platform such limitations are no longer relevant). An additional advantage is the possibility of extending the perspective of observing simulated behavior and collecting (recording) an extended range of data and information. It may refer to the need to examine in detail, for example, a highly variable structure of a business, production, management process, etc., which is difficult to observe in real time. It is worth noting here that, in contrast to traditional mathematical models, which significantly extend the computation time when changing parameters, the time extension may not be significant in simulation models. The results of such simulations can be collected, stored, analyzed and compared not only in complex Big-Data technologies, but also in data warehouse systems (e.g. in OLAP systems).

An important advantage for dynamically changing conditions, which is emphasized by the concept of the fourth industrial revolution and a strong relationship between the customer and the business entity, is the possibility of repeated experiments under the same conditions and in subsequent, definable phases. Such activities in traditional laboratory experiments are rather impossible or very expensive. The advantage of communicating the assessment of the current or prospective situation is the possibility of visualizing the analyzed situations in virtual reality. Such an aspect may be particularly useful in forecasting the course of processes in the conditions of failures and defects and the effects of this in economic systems, because the overall perception and understanding of the situation determines the speed and accuracy of the decision-making process.

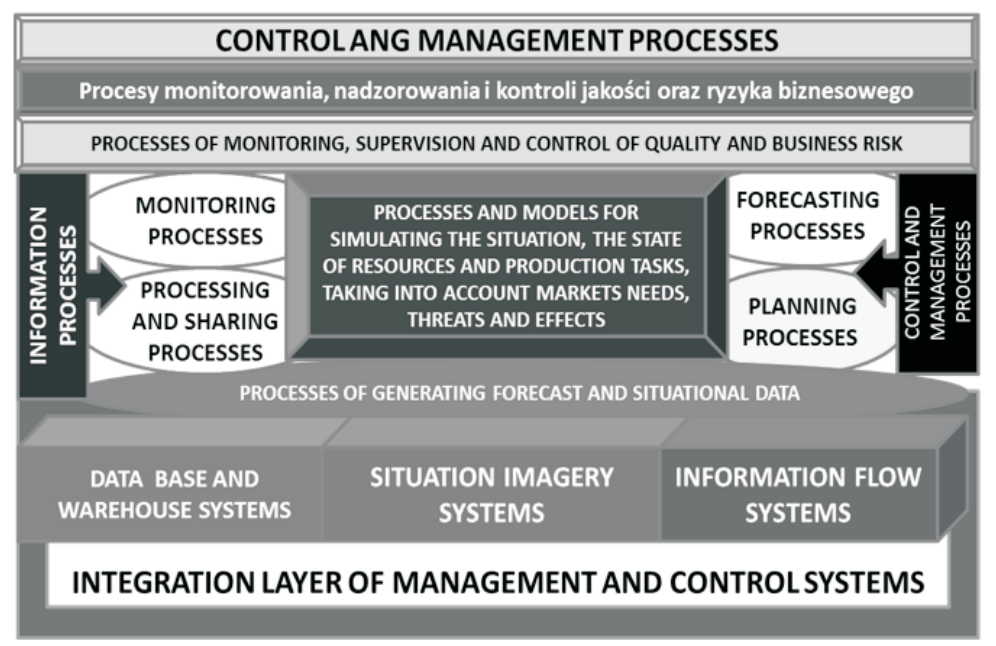

Fig. 4. Complementarity of IT services in the context of simulation models Source: Own study 
Models and simulation systems may play a special role in decision-making processes (Zacharias et al., 2008, pp. 89-118) and in the simulation of e.g. factory production lines, assessment of their service life, endurance, efficiency and reliability of individual workstations (including machines or manufactured products). In the design of various facilities and technical devices (e.g. aircraft), strength tests are carried out with the use of CAx software (e.g. CAD programs). The use of simulation models can enrich the forecasting of the life cycle of a given product, demand and supply research or market research in terms of economic parameters (e.g. production profitability) of a given product. Simulation models can support the study of various systems and objects without significant limitations, except for creating a model that should be closest to a specific reality (Karkula, 2012). With the development of IT technology, creating simulation models is easier and the model itself more and more adequately reflects reality. ${ }^{2}$

Thus, simulation systems and models are becoming a complementary component of technologies determined by the assumptions of the fourth industrial revolution. The close coupling of simulation tools with advanced IT/ICT technologies, especially in the aspect of using the information resources collected there, but also by feeding these resources back with simulation data of particular value and quality - is a confirmation of the possibility of reducing the risk level of an effective implementation of the Industry 4.0 concept.

The fourth industrial revolution aims to eliminate barriers between innovators, recognizes the special role of artificial intelligence, but also its threats, and emphasizes the need to integrate various domains, techniques and technologies. In many cases, implementation restrictions (eg. IoT, IIoT) are mainly limited to legal aspects and service security assurance procedures (eg. in CC). An important challenge is, above all, improving the quality and shaping the lifestyle of society in a turbulent economic, social and technological environment (Min Xu, David, Suk Hi, 2018).

\section{Conclusions}

Operating the correct, up-to-date and reliable information is the basic condition for effective operation. IT tools and platforms increase the chances of achieving the appropriate level of effective management in the conditions of the fourth industrial revolution thanks to multidimensional risk evaluation and ongoing monitoring of various events and threats. Coordination of activities of many people with appropriate, individual executive and management competences on the basis of uniform, communicative information may increase the level of synergy in the management system of a modern organization. The article attempts to present selected platforms

2 The Matrix: Reloaded (2003), The Matrix: Revolutions (2003). 
and tools enhancing the chances of effective development of modern business organizations. These solutions include CC services as well as large data collection systems and data mining models. Supplying these systems with representative and reliable data may take place through the increasing use of the Internet platform, the Internet of Things and, above all, the so-called Industrial Internet (IIoT), as well as simulation models that can dynamically enrich analytical systems with forecasting data and verify forecasted resource states necessary for an effective management process. A comprehensive assessment of the possibilities (available resources) and the needs of taking selected action strategies may increase social trust and the sense of security of the contemporary recipient/customer of various services and products.

Contemporary organizations should effectively assess - in various time horizons and at various stages of the development of the business situation - the forecast and real possibilities of operating using the potential of their environment, including access to selected resources, as well as information services, with quite strong extortion and limitations, both financial and technological. The modern IT/ICT environment enables the effective implementation of information and decision-making processes with the use of standards and resources located on the CC platform along with access to Big-Data technology and ever newer simulation tools and techniques. In addition, many business models can be used to ensure effective operation and maintain the appropriate level of quality of products and services, including those supported by the entire family of technologies, such as OLTP/OLAP/DM/Big-Data systems. Then, there are real conditions for guaranteeing the coherence and integrity of the activities of business entities in a dispersal using a virtual environment with mobile information services, without time and place limitations.

\section{REFERENCES}

[1] Basole, R.C., Park, H., 2019, Interfirm Collaboration and Firm Value in Software Ecosystems: Evidence from Cloud Computing, IEEE Transactions on Engineering Management, No. 66(3).

[2] Chowdhury, N., 2018, Factors Influencing the Adoption of Cloud Computing Driven by Big Data Technology: A Quantitative Study, ProQuest LLC, Ph.D. Dissertation, Capella University.

[3] Da Veiga, A., Astakhova, L.V., Botha, A., Herselman, M., 2020, Defining organisational information security culture - Perspectives from academia and industry, Computers \& Security, No. 92.

[4] Denning, S., 2020, Era Agile. O tym, jak sprytne firmy ksztattuja swoją efektywność, Helion, Gliwice.

[5] Design PRINCIPles, 2020, Design principles for industries 4.0 scenarios (07.09.2020).

[6] Dugan, R.E., Gabriel, K.J., 2013, «Special Forces» Innovation: How DARPA attacks problems, Harvard Business Review, Vol. 91, Issue 10.

[7] ERP24, 2019, https://www.erp24.pl/rynek-it-swiat/5-kluczowych-systemow-big-data-na-swiecie. html; 5 kluczowych systemów Big Data na świecie (12.10.2019).

[8] GajDa, J.B., 2017, Prognozowanie i symulacje w ekonomii i zarzadzaniu, C.H. Beck, Warsaw. 
[9] Gilchrist, A., 2016, Industry 4.0. The Industrial Internet of Things, Apress, New York.

[10] Karkula, M., 2012, Weryfikacja i walidacja dynamicznych modeli symulacyjnych procesów logistycznych, Logistyka, Vol. 2.

[11] Mateos, A., Rosenberg, J., 2010, The Cloud at Your Service. The when, how, and why of enterprise cloud computing, Manning Publications, Greenwich.

[12] Mayer-Schonenberger, V., Cukier, K., 2014, Big Data: A Revolution That Will Transform How We Live, Work, Eamon Dolan/Mariner Books.

[13] Miller, M., 2016, Internet Rzeczy. Jak inteligentne telewizory, samochody, domy i miasta zmieniaja świat, PWN, Warsaw.

[14] Min, Xu, David, J.M., Suk Hi, K., 2018, The Fourth Industrial Revolution: Opportunities and Challenges, International of Financial Research, Vol. 9, No. 2.

[15] Ogórek, M., Zaskórski, P., 2018, Implementation of the Internet of Things (LoT) in the Integration of Crisis Management Processes, Scientific Journals of Poznan University of Technology. Organization and Management, No. 67.

[16] Senhar, A.J., Dvir, D., 2007, Reinventing project management: the diamond approach to successful growth and innovation, Harvard Business School Press.

[17] Vijayakumar, K., Arun, C., 2017, Analysis and selection of risk assessment frameworks for cloud based enterprise applications, Biomedical Research, No. 28.

[18] Zacharias, G.L., Macmillan, J., Van Hemel, S.B. (Eds.), 2008, Behavioral modeling and simulation: From individuals to societies, Committee on Organizational Modeling from Individuals to Societies, The National Academy Press, Washington.

[19] ZASKóRSKI, P. (Ed.), 2011, Managing an organization under the risk of loss of information continuity, Military University of Technology, Warsaw.

[20] Zaskórski, P., 2012, Asymetria informacyjna w zarządzaniu procesami, Military University of Technology, Warsaw.

[21] ZAskóRski, P., WoŹNiAK, J., ZaskóRski, W., 2020, Informational Continuity of Operations in the Context of Safety and Security Research in Contemporary Organizations, 35th IBIMA Conference, Seville.

[22] Zaskórski, P., Zaskórski, W., 2017, Big-Data systems in improving modern organizations, Modern Management Systems, No. 2(12). 